\title{
The impact of land-use change on floristic diversity at regional scale in southern Sweden 600 BC-AD 2008
}

\author{
D. Fredh ${ }^{1}$, A. Broström ${ }^{1,2}$, M. Rundgren ${ }^{1}$, P. Lagerås ${ }^{2}$, F. Mazier ${ }^{3}$, and L. Zillén ${ }^{1}$ \\ ${ }^{1}$ Department of Geology, Quaternary Sciences, Lund University, Sölvegatan 12, 22362 Lund, Sweden \\ ${ }^{2}$ Swedish National Heritage Board, Contract Archaeology Service, Odlarevägen 5, 22660 Lund, Sweden \\ ${ }^{3}$ GEODE, UMR 5602, University of Toulouse-Le Mirail, 5 allées A. Machado, 31058 Toulouse Cedex, France \\ Correspondence to: D. Fredh (daniel.fredh@geol.lu.se)
}

Received: 7 October 2012 - Published in Biogeosciences Discuss.: 21 December 2012

Revised: 16 April 2013 - Accepted: 21 April 2013 - Published: 8 May 2013

\begin{abstract}
This study explores the relationship between landuse and floristic diversity between $600 \mathrm{BC}$ and AD 2008 in the uplands of southern Sweden. We use fossil pollen assemblages and the Regional Estimates of Vegetation Abundance from Large Sites (REVEALS) model to quantitatively reconstruct land cover at a regional scale. Floristic richness and evenness are estimated using palynological richness and REVEALS-based evenness, respectively. We focus on the period AD 350 to 750 to investigate the impact of an inferred, short-lived $(<200 \mathrm{yr})$ period of land-use expansion and subsequent land abandonment on vegetation composition and floristic diversity. The observed vegetation response is compared to that recorded during the transition from traditional to modern land-use management at the end of the 19th century. Our results suggest that agricultural land use was most widespread between AD 350 and 1850, which correlates broadly with high values of palynological richness. REVEALS-based evenness was highest between AD 500 and 1600 which indicates a more equal cover among taxa during this time interval. Palynological richness increased during the inferred land-use expansion after AD 350 and decreased during the subsequent regression AD 550-750, while REVEALS-based evenness increased throughout this period. The values of palynological richness during the last few decades are within the range observed during the last 1650 yr. However, REVEALS-based evenness shows much lower values during the last century compared to the previous ca. $2600 \mathrm{yr}$, which indicates that the composition of presentday vegetation is unusual in a millennial perspective. Our results show that regional scale changes in land use have had clear impacts on floristic diversity in southern Sweden, with
\end{abstract}

a vegetation response time of less than 20 to $50 \mathrm{yr}$. We show the importance of traditional land use to attain high biodiversity and suggest that ecosystem management should include a regional landscape perspective.

\section{Introduction}

One of the main ecological challenges during this century is to mitigate the expected loss of species due to rapid landuse and climate changes (MacDonald et al., 2008; Anton et al., 2010; Barnosky et al., 2011). To make adequate priorities and implement realistic nature conservancy efforts, we need a range of methods to understand how these processes may impact on biodiversity (Dawson et al., 2011). Because ecosystem responses may occur over decades or centuries, making them difficult to observe, palaeobotanical records provide important information about past responses relevant to on-going and future changes in vegetation and biodiversity (Jackson and Hobbs, 2009; Haslett et al., 2010; Willis and Bhagwat, 2010; Willis et al., 2010).

In many areas, such as northwest Europe, agricultural land use has influenced vegetation and biodiversity for thousands of years (Berglund et al., 2008; Emanuelsson, 2009; Willis et al., 2010). The traditional agriculture, including crop cultivation, mowing and animal husbandry, made it possible for plants that do not naturally grow in northwest Europe to immigrate (Emanuelsson, 2009). The rapid land-use changes during the last ca. $100 \mathrm{yr}$, from a small-scaled traditional agriculture towards a modern agriculture based on largescaled crop cultivation and forestry, have led to a decrease in 
available habitats, such as semi-open grasslands, that many species are restricted to (Antonsson and Jansson, 2011).

Land-use transitions have occurred throughout agricultural history (Berglund, 1969; Lagerås, 2007; Froyd and Willis, 2008). By studying these transitions, using highresolution palaeobotanical records, we may reconstruct the rate and degree of change in land use and vegetation. This allows us to better understand how current ecosystems will respond to present and future land-use changes and provide information useful for ecosystem management.

The Landscape Reconstruction Algorithm (LRA) enables new ways to study past land-use and biodiversity changes (Sugita, 2007a, b). Based on pollen counts extracted from lake and mire sediments, LRA, with its submodel Regional Estimates of Vegetation Abundance from Large Sites (REVEALS), compensates for differences in pollen productivity and dispersal characteristics among taxa and makes it possible to quantify past vegetation composition at a regional scale (Sugita, 2007a; Hellman et al., 2009). Moreover, it now makes it possible to reconstruct past floristic diversity using the two parameters: richness and evenness. Richness is the number of species within a specific area, which may be estimated using palynological richness, i.e the number of different pollen taxa found in a sediment sample (Birks and Line, 1992; Odgaard, 1999; Van Dyke, 2008; Meltsov et al., 2011). Evenness is a measure of the relative abundance of the different species that are present within an area (Magurran, 2004), which may be estimated for common taxa by applying evenness indices to the REVEALS output (Fredh et al., 2012). High evenness describes situations when all species within an area are represented by similar spatial cover, whereas low evenness characterizes landscapes where a few species cover large areas and other species cover small areas. For example, an ecosystem with two species that cover $50 \%$ each is ecologically very different from an ecosystem with two species that cover $10 \%$ and $90 \%$, respectively, although the number of species is the same.

Fredh et al. (2012) analyzed the relationship between landuse and floristic diversity during the transition from traditional to modern land-use management AD 1800-2008, using the uplands of southern Sweden as an example. In this study, the record is extended back to $600 \mathrm{BC}$, using a similar approach and the same sediment sequence from Lake Fiolen. The aims are as follows:

- Build a robust chronology to enable quantification of rate of change.

- Analyze the relationship between land-use and floristic diversity during the last $2600 \mathrm{yr}$ at a regional scale (50 km radius) using fossil pollen assemblages and the REVEALS model.

- Specifically study the period AD 350-750 as an example of the impact of a short-lived $(<200 \mathrm{yr})$ period of

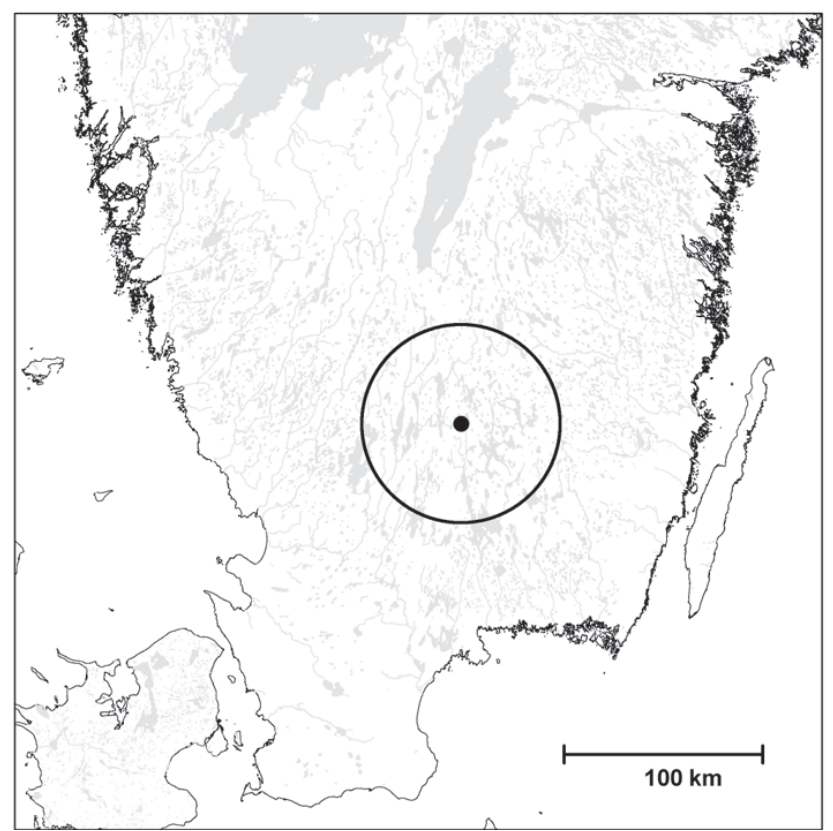

Fig. 1. Study area in the south Swedish Uplands. The circle represents the reconstructed area within a $50 \mathrm{~km}$ radius from Lake Fiolen which is situated in the centre.

land-use expansion followed by abandonment on vegetation composition and floristic diversity.

- Compare the vegetation responses during the inferred agricultural expansion and regression period AD 350-750 with the previous study of the transition from traditional to modern land-use management AD 1800-2008 (Fredh et al., 2012).

- Provide quantitative estimates of long-term (century to millennial scale) impacts of land-use changes on floristic diversity, useful for ecosystem management.

\section{Study area}

The study area is located in the uplands of southern Sweden, above $200 \mathrm{~m}$ a.s.l., in the central part of the province of Småland (Fig. 1). The bedrock is mainly of crystalline granite and gneiss, which is covered by sandy till and some glaciofluvial deposits (Fredén, 1994). The modern tree cover consists of a mixture of coniferous and deciduous forest, which is typical for the boreo-nemoral zone (Sjörs, 1963). The tree cover is $72 \%$, shrubs $1 \%$, herbs $21 \%$ and Cerealia $6 \%$, with Picea and Pinus as the dominant trees (Hellman et al., 2008b). Mean annual temperatures are $5-7^{\circ} \mathrm{C}$, and mean annual precipitation varies from ca. 600 to ca. $1200 \mathrm{~mm}$ (Raab and Vedin, 1995).

Compared to lower areas, the uplands of southern Sweden have relatively poor soil conditions, and the agricultural activity has therefore been relatively low, although pollen 
records and archaeological evidence show that there has been a pattern of expansion and regression phases of agricultural land use during the last $6000 \mathrm{yr}$ (Hyenstrand, 1979; Berglund et al., 2002; Poschlod et al., 2005). During the Iron Age (500 BC to AD 1050) some settlements became organized in hamlets and villages but single farms dominated (Welinder et al., 2004).

From ca. AD 1000, agriculture in the upland area was dominated by permanently farmed land, with clear separation between cultivated fields, meadows and common land around the farms used for grazing (Berglund et al., 2002). The medieval expansion (ca. AD 900-1200) was interrupted by the late medieval agrarian crisis, when marginal areas were abandoned for better soils (Berglund et al., 2002; Myrdal, 2003; Emanuelsson, 2005; Lagerås, 2007). Historical documents from the 17th century reveal that parts of the uplands were regularly cleared with fire, and used for temporary cultivation as a complement to more permanent fields (Larsson, 1974). During the agricultural revolution (ca. AD 1700-1900) arable fields were combined to form larger units, and the common land was split up and divided between farmers (Gadd, 2000). The maximum extent of agricultural land use occurred in the late 19th century. Since then Picea plantations and cultivated fields have expanded and dominate the land use today (Morell, 2001).

Within the past $2000 \mathrm{yr}$, there have been some significant climate changes in the northern Hemisphere, such as the Medieval Warm Period (11th and 12th century) and the Little Ice Age (16th to 17th century) with an overall temperature range of about $0.7^{\circ} \mathrm{C}$ (before AD 1990) (Moberg et al., 2005). However, in this paper we assume that anthropogenic land use is the main driver for floristic diversity changes, mainly because many herbs are related to the open lands related to the traditional agriculture, such as cultivated fields, meadows and pastures. Moreover, it could be expected that the conditions in the relatively low uplands in southern Sweden $(<400 \mathrm{~m}$ a.s.l.) did not limit the plant growth much, e.g. agricultural crops were common during the Little Ice Age (Lagerås, 2007).

\section{Methods}

\subsection{Field work and core correlation}

During fieldwork in June 2008, overlapping sediment cores were retrieved from Lake Fiolen (160 ha) using Kajak (core K) (Renberg and Hansson, 2008), Russian (core C and D) (Aaby and Digerfeldt, 1986) and piston (core P) corers (Fig. 2a). Correlations between the cores were carried out using mineral magnetic properties (Thompson et al., 1980) and element compositions based on X-ray fluorescence measurements (Boyle, 2000). For more details on methods used for core correlation see Fredh et al. (2012). All analyses were carried out on core $\mathrm{K}$ and $\mathrm{P}$, except for a few radiocarbon datings performed on core $\mathrm{C}$ and $\mathrm{D}$.

\subsection{Dating}

\subsubsection{Radiocarbon}

${ }^{14} \mathrm{C}$ dating was used to date organic remains in the sediment sequence. Thirteen macrofossil samples and eight bulk gyttja samples were dated using accelerator mass spectroscopy (AMS) at the Radiocarbon Dating Laboratory at Lund University (Table 1). Three of the macrofossil samples were taken from correlated parallel cores, introducing an estimated depth uncertainty of $<2 \mathrm{~cm}$. The macrofossils were extracted from the sediments using a $250 \mu \mathrm{m}$ sieve. Only very small amounts were found, and terrestrial material was identified in most samples. Because of very small sample sizes, pre-treatment $(\mathrm{HCl}$ and $\mathrm{NaOH})$ could only be carried out for three of the macrofossil samples. Only six of the dated macrofossil samples were used to construct the age-depth model (see below). The OxCal program (v. 4.1.7) and the CaliBomb program were used for calibration of ${ }^{14} \mathrm{C}$ dates based on calibration curves constructed from terrestrial and atmospheric samples (Levin and Kromer, 2004; Levin et al., 2008; Reimer et al., 2009).

\subsubsection{Lead-210 and Caesium-137}

${ }^{210} \mathrm{~Pb}$ dating was used to date the uppermost part of the sediment sequence. In all, 26 samples ( 21 from core $\mathrm{K}$ and five from core $\mathrm{P}$ ) between 0 and $44 \mathrm{~cm}$ depth were analysed for the activity of ${ }^{210} \mathrm{~Pb},{ }^{137} \mathrm{Cs}$ and ${ }^{226} \mathrm{Ra}$. The samples were analysed via gammaspectrometry at the Gamma Dating Centre, Institute of Geography at the University of Copenhagen, Denmark. The fraction of total ${ }^{210} \mathrm{~Pb}$ that is deposited on the lake surface from the atmosphere (i.e. the unsupported ${ }^{210} \mathrm{~Pb}$ ) was calculated based on the ${ }^{226} \mathrm{Ra}$ data obtained. The irregular profile of ${ }^{210} \mathrm{~Pb}$ below $15 \mathrm{~cm}$ allows for different calculation options using the Constant Rate of Supply (CRS) model (Fig. 2e; Appleby, 2001). Fredh et al. (2012) included 20 samples in the CRS model, whereas in this study we only included the nine samples above $15 \mathrm{~cm}$ (Fig. 2, Sect. 4.1). Below $15 \mathrm{~cm}$ the activity of ${ }^{210} \mathrm{~Pb}$ was calculated by assuming a constant sedimentation rate. Variations in ${ }^{137} \mathrm{Cs}$ activity can be used as time markers and this isotope was therefore measured with the aim to validate the CRS-model (Appleby, 2001).

\subsubsection{Lead pollution history}

Atmospheric lead deposition recorded in lake sediments was used as an independent dating tool. Pollution lead originates from historical mining activities and emissions from combustion of leaded petrol. Total lead concentrations and lead isotope ratios $\left({ }^{206} \mathrm{~Pb} /{ }^{207} \mathrm{~Pb}\right)$ measured in sediments which reflect the pollution history are similar between lakes in 


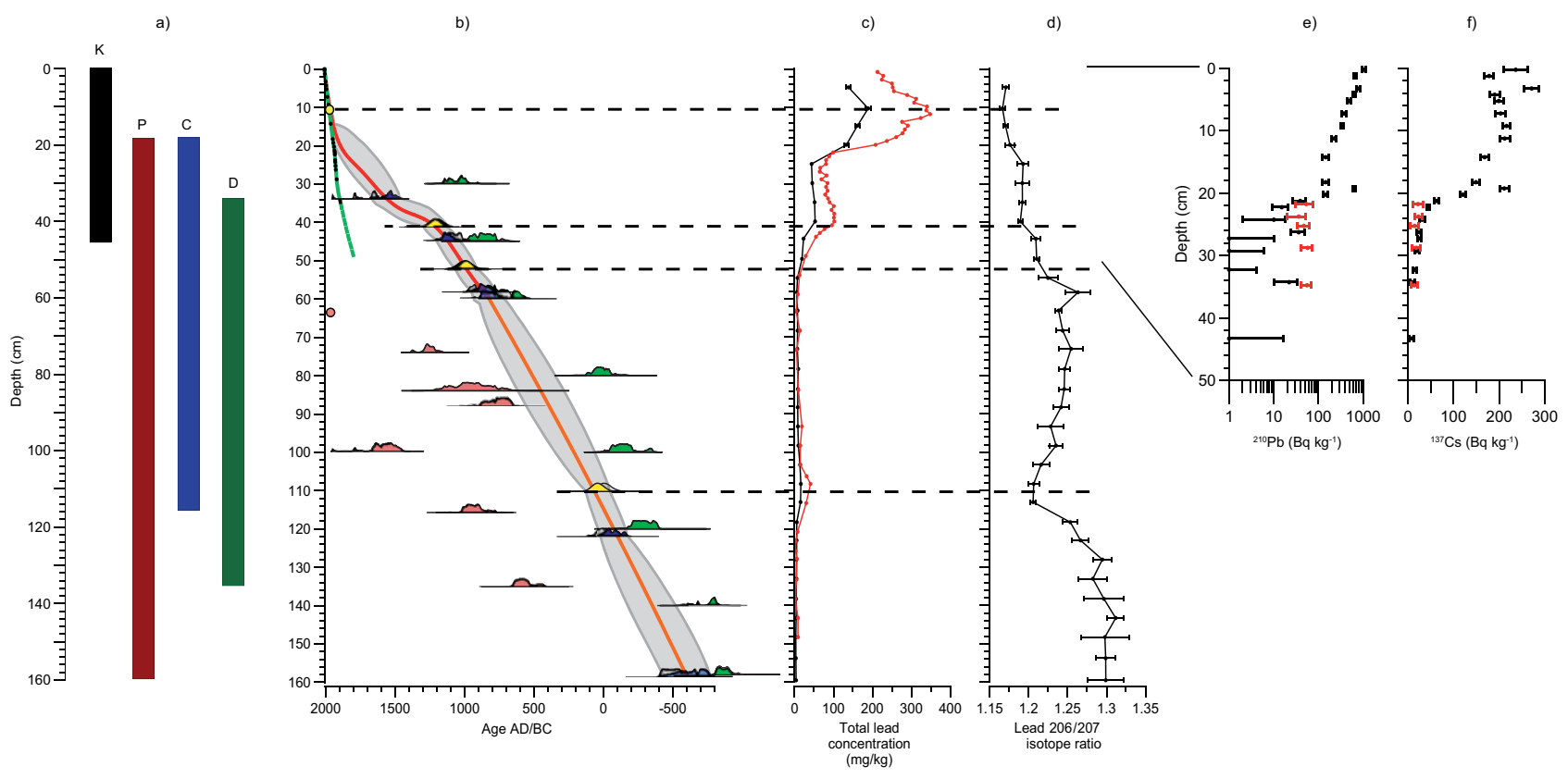

Fig. 2. (a) Cores used in this study. (b) Age model established by the OxCal program when including six radiocarbon dates based on three large ( $>2 \mathrm{mg}$ ) macrofossils (dark blue) and three small ( $<2 \mathrm{mg}$ ) macrofossils (light blue), a CRS-model based on nine ${ }^{210} \mathrm{~Pb}$ samples (black dots above $15 \mathrm{~cm}$ ), and four lead pollution markers (yellow, Brännvall et al., 2001). Seven radiocarbon dates based on small macrofossils (red), eight bulk radiocarbon dates (green) and all ${ }^{210} \mathrm{~Pb}$ samples below $15 \mathrm{~cm}$ were excluded when constructing the model. Two polynomial functions, one above (red line) and one below $60 \mathrm{~cm}$ (orange line), with a polynomial order of seven and two, respectively, were fitted to the midpoints of the calibrated $2 \sigma$ intervals (grey) provided by $\mathrm{OxCal}$ and used to calculate ages for the sequence at $0.5 \mathrm{~cm}$ intervals. Green line represents the age/depth model used in Fredh et al. (2012). (c) Total lead concentrations measured using Quadrapole ICP-MS (black line) and XRF (red line), respectively. (d) Lead 206/207 ratio. (e, f) Unsupported ${ }^{210} \mathrm{~Pb}$ and ${ }^{137} \mathrm{Cs}$ concentrations measured on core $\mathrm{K}$ (black) and core $\mathrm{P}$ (red).

Sweden and may be used as a chronological framework (Brännvall et al., 2001; Renberg et al., 2001). Time markers may be identified at AD 0 (Roman peak), AD 900-1000 (Medieval expansion), AD 1200 (Medieval peak) and AD 1975 (Modern maximum). The highest amount of lead emissions occurred between the 1950s and the 1970s, and the highest lead concentrations in sediments are found in the interval corresponding to this age. The total lead concentrations in lake sediments show a gradient with higher values in the south compared to the north, which reflects the pattern of dispersal from south and central Europe. Sulphide ores used in medieval times have a typical lead isotope ratio of about 1.17 and emissions from petrol a typical ratio of 1.15. Both of these are lower than the natural isotope ratio of bedrocks in Sweden.

Lead was measured at $1 \mathrm{~cm}$ intervals in the upper sediment core (core $\mathrm{K}$ ) and at between 1 and $11 \mathrm{~cm}$ intervals in the lower sediment core (core P) using X-ray Florescence (XRF) to estimate total lead concentration (Boyle, 2000), and at ca. $5 \mathrm{~cm}$ intervals using Acid Dissolution (EPA 3052) and Quadrapole ICP-MS to estimate both total lead concentration and lead isotope composition. The XRF measurements were carried out at the Environmental Magnetism Laboratory at the Department of Geography, Liverpool University, UK, and the Acid Dissolution (EPA 3052) and Quadrapole ICPMS measurements at the Department of Geography, Durham University, UK. In the absence of a standard method to infer uncertainty estimates for the pollution markers, we used an approximation of $50 \mathrm{yr}$ uncertainty for all markers except the modern maximum at $\mathrm{AD} 1975$, which was assigned an uncertainty of $5 \mathrm{yr}$.

\subsubsection{Age modelling}

Because of inconsistencies within and between the chronological data provided by the different methods applied, we had to be selective in the use of data points in the final agedepth model. We chose to include all pre-treated macrofossils and as many small macrofossil samples and lead pollution markers as possible. However, using this option we had to exclude most of the samples analyzed for ${ }^{210} \mathrm{~Pb}$-activity used in the CRS-model and most of the small macrofossil samples. We also assumed that our interpretations of the total lead and lead isotopes data used for time markers are correct.

Using our preferred chronological data, the OxCal program (v. 4.1.7) was used to establish a chronology for the entire sediment sequence using Bayesian analysis (Bronk Ramsey, 2009). The age model was established using a 
Table 1. Radiocarbon dates on macrofossils and bulk sediment samples. Calibrated age intervals are those provided by the OxCal program when calculated for each sample individually (not in a sequence). The ${ }^{14} \mathrm{C}$ age for sample LuS8602 is younger than AD 1950 and therefore expressed as percent modern carbon (pMC). Sample weights are those reported by the laboratory for material used for graphitization (after any pre-treatment). Weights for the first dated sample batches (LuS8XXX) were reported as mg organic material, while weights for samples dated later were reported as $\mathrm{mg} \mathrm{C}$.

\begin{tabular}{|c|c|c|c|c|c|c|c|c|}
\hline \multicolumn{9}{|c|}{ Macrofossils } \\
\hline Lab-ID & $\begin{array}{l}\text { Depth } \\
(\mathrm{cm})\end{array}$ & $\begin{array}{l}{ }^{14} \mathrm{C} \text { age } \mathrm{BP} \\
\quad \pm 1 \sigma\end{array}$ & $\begin{array}{l}\text { Calibrated age } \\
\mathrm{BP}(1 \sigma \text { interval })\end{array}$ & $\begin{array}{c}\text { Calibrated age } \\
\mathrm{AD} / \mathrm{BC}(1 \sigma \text { interval })\end{array}$ & $\begin{array}{l}\text { weight } \\
\text { (mg) }\end{array}$ & $\begin{array}{l}\text { Pre- } \\
\text { treatment }\end{array}$ & $\begin{array}{l}\text { Type of } \\
\text { material }\end{array}$ & Core \\
\hline LuS9161 & 33.75 & $260 \pm 50$ & $429--1$ & AD 1521-1951 & $3.1(\mathrm{C})$ & $\mathrm{HCl}, \mathrm{NaOH}$ & Twig & $\mathrm{P}$ \\
\hline LuS9103 & 44.50 & $950 \pm 50$ & $925-796$ & AD 1025-1154 & $2.1(\mathrm{C})$ & $\mathrm{HCl}, \mathrm{NaOH}$ & Plant remains & $\mathrm{C}$ \\
\hline LuS9105 & 58.00 & $1160 \pm 45$ & $1170-1000$ & AD 780-950 & $1.29(\mathrm{C})$ & - & Plant remains & $\mathrm{D}$ \\
\hline LuS9104 & 59.50 & $1255 \pm 50$ & $1274-1141$ & AD 676-809 & $0.52(\mathrm{C})$ & - & Plant remains & $\mathrm{C}$ \\
\hline LuS8602 & 63.75 & $105.5 \pm 0.7 \mathrm{pMC}$ & $-3--57$ & AD 1953-2007 & 0.39 (org. mtrl) & - & $\begin{array}{l}\text { Leaf + Betula } \\
\text { catkin scale }\end{array}$ & $\mathrm{P}$ \\
\hline LuS8603 & 73.75 & $750 \pm 60$ & $734-658$ & AD 1216-1292 & 0.15 (org. mtrl) & - & $\begin{array}{l}\text { Betula catkin } \\
\text { scale }\end{array}$ & $\mathrm{P}$ \\
\hline LuS8061 & 83.75 & $1070 \pm 120$ & $1169-803$ & AD 781-1147 & 0.15 (org. mtrl) & - & Alnus fruit & $\mathrm{P}$ \\
\hline LuS8604 & 87.50 & $1260 \pm 60$ & $1279-1095$ & AD 671-855 & 0.57 (org. mtrl) & - & $\begin{array}{l}\text { Plant remains + } \\
\text { Betula } \\
\text { catkin scale }\end{array}$ & $\mathrm{P}$ \\
\hline LuS8605 & 99.50 & $300 \pm 60$ & $456-299$ & AD 1494-1651 & 0.29 (org. mtrl) & - & $\begin{array}{l}\text { Moss + Betula catkin } \\
\text { scale + plant remains }\end{array}$ & $\mathrm{P}$ \\
\hline LuS8606 & 115.50 & $1095 \pm 60$ & 1060-937 & AD 890-1013 & 0.53 (org. mtrl) & - & $\begin{array}{l}\text { Leaf }+ \text { Betula catkin } \\
\text { scale }+ \text { plant remains }\end{array}$ & $\mathrm{P}$ \\
\hline LuS8062 & 121.75 & $1995 \pm 50$ & $1995-1887$ & $45 \mathrm{BC}-\mathrm{AD} 63$ & 3.8 (org. mtrl) & $\mathrm{HCl}, \mathrm{NaOH}$ & Leaf & $\mathrm{P}$ \\
\hline LuS8607 & 134.75 & $1475 \pm 60$ & $1408-1306$ & AD 542-644 & 0.34 (org. mtrl) & - & Plant remains & $\mathrm{P}$ \\
\hline LuS8608 & 158.25 & $2440 \pm 60$ & $2695-2359$ & 745-409 BC & 0.17 (org. mtrl) & - & $\begin{array}{l}\text { Leaf + Betula } \\
\text { fruit }\end{array}$ & $\mathrm{P}$ \\
\hline \multicolumn{9}{|c|}{ Bulk sediments } \\
\hline Lab-ID & $\begin{array}{l}\text { Depth } \\
(\mathrm{cm})\end{array}$ & $\begin{array}{l}{ }^{14} \mathrm{C} \text { age } \mathrm{BP} \\
\quad \pm 1 \sigma\end{array}$ & $\begin{array}{l}\text { Calibrated age } \\
\text { BP }(1 \sigma \text { interval })\end{array}$ & $\begin{array}{c}\text { Calibrated age } \\
\mathrm{AD} / \mathrm{BC}(1 \sigma \text { interval })\end{array}$ & $\begin{array}{l}\text { weight } \\
(\mathrm{mg})\end{array}$ & $\begin{array}{l}\text { Pre- } \\
\text { treatment }\end{array}$ & $\begin{array}{l}\text { Type of } \\
\text { material }\end{array}$ & Core \\
\hline LuS9616 & 29.75 & $995 \pm 50$ & $961-800$ & AD 989-1150 & $4.1(\mathrm{C})$ & HCL & Bulk & $\mathrm{P}$ \\
\hline LuS9617 & 44.75 & $1165 \pm 50$ & $1171-1005$ & AD 779-945 & $4.3(\mathrm{C})$ & HCL & Bulk & $\mathrm{P}$ \\
\hline LuS9618 & 59.75 & $1415 \pm 50$ & $1353-1290$ & AD 597-660 & $4.3(\mathrm{C})$ & HCL & Bulk & $\mathrm{P}$ \\
\hline LuS9619 & 79.75 & $1975 \pm 50$ & $1988-1878$ & $38 \mathrm{BC}-\mathrm{AD} 72$ & $5.0(\mathrm{C})$ & HCL & Bulk & $\mathrm{P}$ \\
\hline LuS9620 & 99.75 & $2110 \pm 50$ & 2146-2004 & $196-54 \mathrm{BC}$ & $5.3(\mathrm{C})$ & HCL & Bulk & $\mathrm{P}$ \\
\hline LuS9621 & 119.75 & $2220 \pm 50$ & $2320-2156$ & $370-206$ BC & $5.0(\mathrm{C})$ & $\mathrm{HCL}$ & Bulk & $\mathrm{P}$ \\
\hline LuS9622 & 139.75 & $2590 \pm 50$ & $2771-2546$ & $821-596$ BC & $5.0(\mathrm{C})$ & HCL & Bulk & $\mathrm{P}$ \\
\hline LuS9623 & 157.75 & $2700 \pm 50$ & $2845-2761$ & $895-811$ BC & $5.3(\mathrm{C})$ & $\mathrm{HCL}$ & Bulk & $\mathrm{P}$ \\
\hline
\end{tabular}

P-sequence which takes the stratigraphic levels of dated samples into account and allows for fluctuations in sedimentation rate (Bronk Ramsey, 2008). The degree of fluctuation allowed for by the program may be modified by varying the $\mathrm{k}$-value (the number of accumulation events per unit depth). This parameter was chosen as high as possible to obtain an agreement index $\geq 60 \%$ for the entire age model (Bronk Ramsey, 2008). Two polynomial functions, one above and one below $60 \mathrm{~cm}$, with a polynomial order of seven and two, respectively, were fitted to the midpoints of the calibrated $2 \sigma$ intervals provided by $\mathrm{OxCal}$ and used to calculate age estimates for the sequence at $0.5 \mathrm{~cm}$ intervals.

\subsection{Quantitative reconstruction of land cover}

Material for pollen analysis was subsampled at 0.5 to $10 \mathrm{~cm}$ intervals from the sediment cores from Lake Fiolen and prepared using standard methods (Berglund and RalskaJasiewiczowa, 1986). Pollen grains were identified using a light microscope, identification keys (Beug, 1961, 2004; Punt, 1976-2003; Moore et al., 1991) and the reference collection at the Department of Geology, Lund University. Subsequently, pollen counts from several levels were pooled together to attain at least 1000 grains for each time window, varying in width between 20 and $60 \mathrm{yr}$ as inferred from the chronology. The use of time windows, in sequences when sedimentation rate and sample resolution are high, allows us to capture vegetation changes rather than weather conditions because pollen productivity may change between individual years when sedimentation rate and sample resolution are high (Hicks, 1999; Autio and Hicks, 2004).

Based on pollen counts for each time window, we used the REVEALS program (v. 4.2.2, Sugita, unpublished) to 
provide quantitative estimates of vegetation composition at a regional scale (within a $50 \mathrm{~km}$ radius) between $600 \mathrm{BC}$ and AD 2008. The REVEALS model is an objective way to estimate vegetation composition by compensating for known biases in how vegetation is represented in the pollen record (Sugita, 2007a). Previously, estimates of actual vegetation have been difficult to obtain due to differences in pollen productivity and dispersal characteristics between taxa (Sugita, 1994, 2007a; Broström et al., 1998; Sugita et al., 1999; Davis, 2000). Tree taxa are in general over-represented, and many herb taxa often under-represented, in pollen assemblages compared to their abundance in the surrounding vegetation (Bradshaw and Webb, 1985; Broström et al., 1998; Sugita et al., 1999; Davis, 2000).

The REVEALS model requires various parameter inputs. We used pollen productivity estimates (PPEs), including their standard errors (SEs), obtained for 26 taxa (Table 2) from southern Sweden and Denmark and fall speed estimates of pollen from the literature (Eisenhut, 1961; Sugita et al., 1999; Broström et al., 2004, 2008; Nielsen, 2004). The REVEALS version used in this study (v. 4.2.2) assumes neutral atmospheric conditions and wind speed $3 \mathrm{~m} \mathrm{~s}^{-1}$ as in Prentice (1985) and Sugita (1993, 1994, 2007a, b). We used a mean radius of $714 \mathrm{~m}$ for Lake Fiolen, calculated from the total lake surface area, assuming this is the area of a circular basin. The maximum spatial extent of the regional vegetation $\left(Z_{\max }\right)$ was set to $50 \mathrm{~km}$ as most of the pollen grains found originate from within this area (Hellman et al., 2008a, b) as recommended by Mazier et al. (2012).

We used the pollen dispersal-deposition function appropriate for lakes, which assumes that pollen grains deposited on a lake surface are totally mixed and evenly deposited on the basin floor (Sugita, 1993). Standard errors for the estimates of regional vegetation abundance were calculated in the REVEALS program using a hybrid of the delta method (Stuart and Ord, 1994) and Monte Carlo simulations (Sugita, 2007a).

\subsection{Reconstruction of floristic diversity}

In this study we used palynological richness and REVEALSbased evenness as proxies for floristic diversity and floristic evenness, respectively (Birks and Line, 1992; Fredh et al., 2012). Palynological richness is the number of different pollen and spore taxa identified in each sample (Birks and Line, 1992), whereas REVEALS-based evenness is the relative abundance between the taxa reconstructed by the REVEALS model (Fredh et al., 2012).

Due to different total pollen counts between time windows the palynological richness was recalculated using rarefaction (Birks and Line, 1992). We therefore present the results of palynological richness as the expected number of pollen taxa for a specific pollen sum. The calculation was based on all terrestrial taxa, in total 17 trees, 66 herbs and 9 ferns. We are aware that the relationship between pollen identified in sediments and the surrounding vegetation is complex,
Table 2. Fall speed of pollen, relative pollen productivity estimates (PPE) and associated standard error estimates (SE) for 26 taxa obtained for southern Sweden (Sugita et al., 1999; Broström et al., 2004) and Denmark (numbers in bold; Nielsen et al., 2004) used in the REVEALS model run.

\begin{tabular}{lccc}
\hline Pollen taxa & Fall speed $\left(\mathrm{m} \mathrm{s}^{-1}\right)$ & PPE & SE \\
\hline Acer & 0.056 & 1.267 & 0.452 \\
Alnus & 0.021 & 4.200 & 0.140 \\
Betula & 0.024 & 8.867 & 0.134 \\
Calluna vulgaris & 0.038 & $\mathbf{1 . 1 0 2}$ & $\mathbf{0 . 0 5 4}$ \\
Carpinus & 0.042 & 2.533 & 0.070 \\
Cerealia-t & 0.060 & $\mathbf{0 . 7 4 7}$ & $\mathbf{0 . 0 3 9}$ \\
Comp. SF. Cichorioideae & 0.051 & 0.244 & 0.065 \\
Corylus & 0.025 & 1.400 & 0.042 \\
Cyperaceae & 0.035 & 1.002 & 0.164 \\
Fagus & 0.057 & 6.667 & 0.173 \\
Filipendula & 0.006 & 2.480 & 0.821 \\
Fraxinus & 0.022 & 0.667 & 0.027 \\
Juniperus & 0.016 & 2.067 & 0.036 \\
Picea & 0.056 & 1.757 & 0.000 \\
Pinus & 0.031 & 5.663 & 0.000 \\
Plantago lanceolata & 0.029 & $\mathbf{0 . 8 9 7}$ & $\mathbf{0 . 2 3 5}$ \\
Poaceae & 0.035 & 1.000 & 0.000 \\
Potentilla-t & 0.018 & 2.475 & 0.377 \\
Quercus & 0.035 & 7.533 & 0.083 \\
Ranunculus acris-t & 0.014 & 3.848 & 0.718 \\
Rubiaceae & 0.019 & 3.946 & 0.589 \\
Rumex acetosa-t & 0.018 & $\mathbf{1 . 5 5 9}$ & $\mathbf{0 . 0 8 9}$ \\
Salix & 0.022 & 1.267 & 0.313 \\
Secale-t & 0.060 & 3.017 & 0.052 \\
Tilia & 0.032 & 0.800 & 0.029 \\
Ulmus & 0.032 & 1.267 & 0.050 \\
\hline & & &
\end{tabular}

and that the pollen grains found in sediments only represent a small portion of all species in surrounding vegetation (Odgaard, 1994, 2007; Peros and Gajewski, 2008; van der Knaap, 2009). However, as a relative measure of floristic diversity, palynological richness has shown to be reliable (Meltsov et al., 2011, 2013).

Based on the proportional abundances estimated by the REVEALS model we calculated the Shannon index, which combines the number of taxa and the relative abundance between taxa to estimate floristic diversity (Magurran, 2004; Odgaard, 2007; van Dyke, 2008). Subsequently, we calculated floristic evenness using the ratio between Shannon index and maximum evenness, when all taxa are equally frequent, also known as the Pielou's evenness index (Pielou, 1966; Magurran, 2004; Odgaard, 2007). Pielou's evenness index may vary between 0 and 1 . The index is 1 when all taxa cover equal proportions of the reconstructed area. Lower values are attained when a few taxa cover large proportions and other taxa cover small proportions within the $50 \mathrm{~km}$ radius. We estimated REVEALS-based evenness for all 26 taxa (14 trees and 12 herbs) used in the REVEALS model, but also for trees and herbs separately. These 26 taxa represent 
about $70-90 \%$ of the total vegetation cover in the upland area of southern Sweden today (Broström et al., 2004).

\section{Results}

\subsection{Chronology}

The radiocarbon dated macrofossil samples show rather scattered ages (Table 1, Fig. 2b). Most of the macrofossil samples were smaller than two milligram and therefore not pretreated. This means that any contamination with modern material during extraction, storage and identification, that would have a relatively strong influence on the dating results of these small samples, was not removed. An extreme case of this effect is probably illustrated by sample LuS8602 from a depth of $63.75 \mathrm{~cm}$, which yielded a modern or close to modern age (Table 1). Because of unexpectedly young ages due to suspected contamination, most of the small macrofossil samples were rejected and not used to construct the age model. We included all pre-treated macrofossil samples that were considered to be most reliable. We also included three small macrofossil samples that were in agreement with the pre-treated macrofossil samples and our interpretation of the lead pollution time markers. The bulk dates show a rather well-defined slope with increased age at greater depth, indicating that the sediments have not been subject to major mixing or disturbance. The absolute ages for these samples are, however, likely affected by a lake reservoir age and therefore assumed to be too old (ca. 200 to $400 \mathrm{yr}$ ) and not used for the chronology.

The activity of unsupported ${ }^{210} \mathrm{~Pb}$ in the sediment sequence generally decreases exponentially with depth down to about $15 \mathrm{~cm}$ (Fig. 2e), while below this depth the activity data are rather irregular. As explained above, we therefore only included the nine lead dates above $15 \mathrm{~cm}$ in the CRSmodel calculation. However, using only the lead dates from above $15 \mathrm{~cm}$ we have to assume that some mixing has occurred and/or that some of the measured elements are mobile in this particular sediment below this depth. That some elements are mobile is supported by the high activity of ${ }^{137} \mathrm{Cs}$ at depths below $14 \mathrm{~cm}$ that correspond to ages older than ca. AD 1950 according to the CRS-model (Fig. 2f). ${ }^{137} \mathrm{Cs}$ is normally only found in sediments younger than AD 1950 (Appleby, 2001).

Time markers were inferred from the total lead concentrations and lead isotope ratios based on comparison with the typical pattern of pollution lead through time for southern Sweden (Brännvall et al., 2001; Renberg et al., 2001). For our age model we used time markers at $110 \mathrm{~cm}, 55 \mathrm{~cm}$, ca. $38 \mathrm{~cm}$, and $11 \mathrm{~cm}$ interpreted to represent AD 0, AD 1000, AD 1200 and AD 1975, respectively (Fig. 2b-d). At $110 \mathrm{~cm}$ total lead concentration increases to $16 \mu \mathrm{g} \mathrm{g}^{-1}$ and the lead isotope $\left({ }^{206} \mathrm{~Pb} /{ }^{207} \mathrm{~Pb}\right)$ ratio decreases with 0.12 . Between 100 and $55 \mathrm{~cm}$ depth the lead isotope ratio increases and the to- tal concentration decreases which may reflect the decline in mining activities between AD 400 and 900 . Between 55 and $38 \mathrm{~cm}$ total lead concentration increases to $53 \mu \mathrm{g} \mathrm{g}^{-1}$ and the lead isotope ratio decreases with 0.13 compared to background values. At $11 \mathrm{~cm}$ the highest total concentration of $189 \mathrm{\mu g} \mathrm{g}^{-1}$ is recorded which we interpret to reflect the pollution maximum at AD 1975. The lead isotope ratio close to or below 1.17 above $19 \mathrm{~cm}$ indicates that a large proportion of the lead found in this interval is derived from pollution from leaded petrol during the 20th century, which has an isotope ratio of ca. 1.15.

Because of inconsistencies within and between the chronological data provided by the different methods applied, dating of the Lake Fiolen sequence is not straightforward. Our preferred age-depth model is based on six macrofossil samples (three pre-treated), a CRS-model (based on nine ${ }^{210} \mathrm{~Pb}$ samples) and four lead pollution markers (Fig. 2b). We therefore rejected eight small macrofossil samples and $17{ }^{210} \mathrm{~Pb}$ measured samples below $15 \mathrm{~cm}$ that were considered unreliable.

Consequently, the proposed age model is tentative, in particular between AD 1200 and AD 1950. It should also be pointed out that our age model for the interval between 0 and $48 \mathrm{~cm}$ differs from that used by Fredh et al. (2012), resulting in deviating age estimates in the lower part of this interval.

\subsection{Long-term ecological changes $600 \mathrm{BC}-\mathrm{AD} 2008$}

Vegetation cover was quantified using REVEALS for the 26 taxa (14 trees and 12 herbs) (Fig. 3). Although the relative importance of taxa is different between the REVEALS-based reconstruction and pollen percentages, their trends are similar. The importance of Picea, Acer, Corylus, Fagus, Poaceae, Cerealia type, Carpinus, Fraxinus, Salix, Tilia, Ulmus, Calluna vulgaris, Compositae SF. Cichorioideae, Cyperaceae, Plantago lanceolata and Secale type is underestimated by pollen percentages, while Pinus, Alnus, Betula, Quercus, Juniperus, Filipendula, Ranunculus acris type and Rumex acetosa type are overestimated by pollen percentages compared to REVEALS-based vegetation cover.

According to the herb taxa cover estimated by REVEALS, landscape openness varies between 5 and $34 \%$ throughout the studied period (Fig. 4). However, we know from the historical record that some light-demanding shrubs grew on meadows and pastures (Antonsson and Jansson, 2011). We may therefore assume that Corylus and Juniperus mainly grew on open lands. When including these shrubs openness varies between 18 and $60 \%$ (Fig. 4). In either case, maximum openness is recorded between AD 350 and 550, mainly due to the increase in Poaceae cover during this time.

During the studied period palynological richness varies between 21 and 38, with the highest value at AD 1600 (Fig. 4). REVEALS-based evenness varies between 0.83 and 0.54, with maximum evenness between AD 500 and 1600 . Evenness for trees is almost identical to total evenness, which 

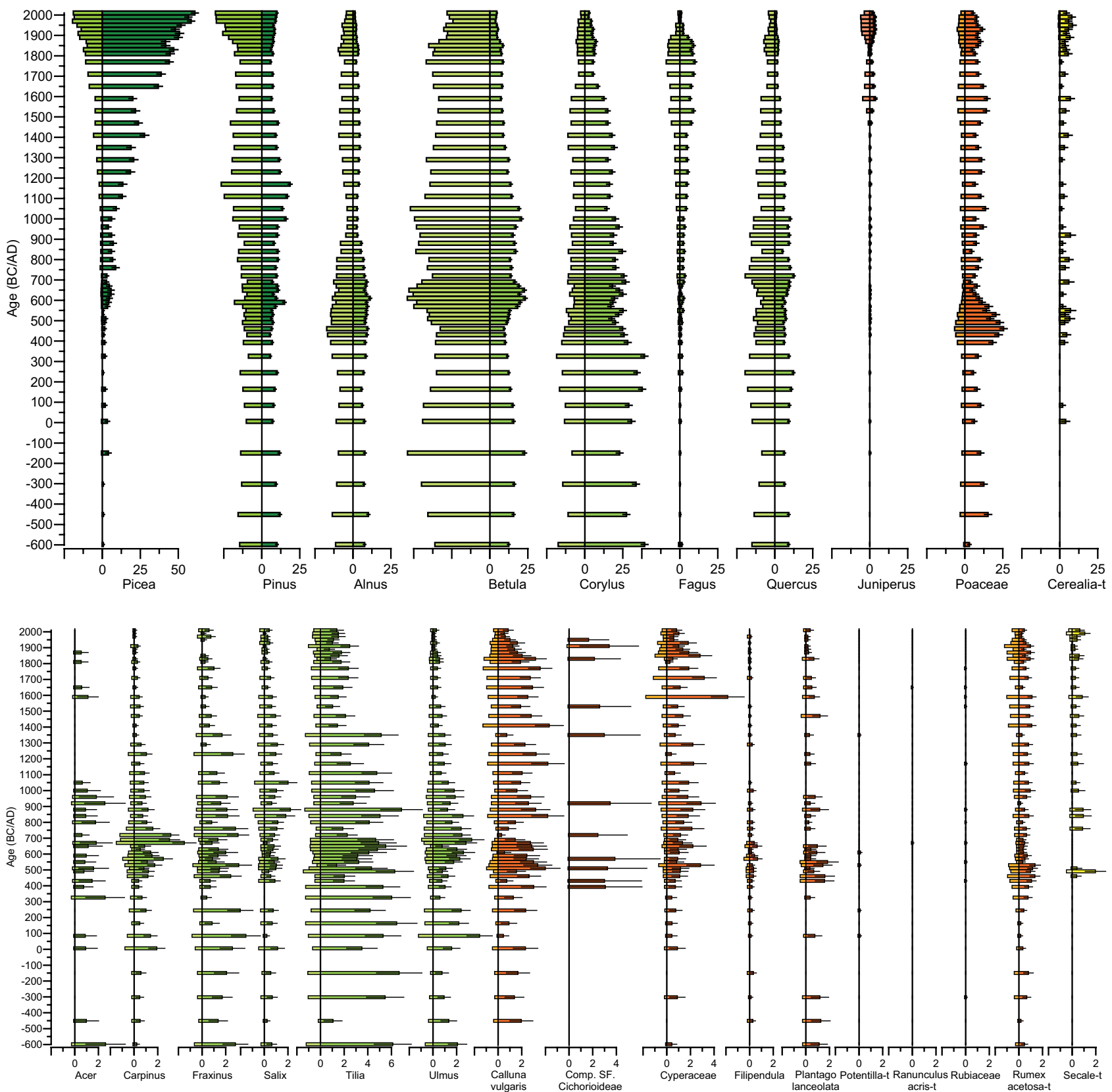

Fig. 3. Pollen percentage diagram (left side) and estimated regional vegetation cover using the REVEALS model (right side) for 26 taxa for the period $600 \mathrm{BC}$ to $\mathrm{AD} 2008$. Note the different scales for the upper and lower parts of the figure.

shows that the tree evenness dominate the total evenness calculation. Evenness for herbs was generally higher the last $1400 \mathrm{yr}$, but rather variable.

Several major vegetation changes occurred during the last $2600 \mathrm{yr}$ according to the REVEALS reconstruction (Fig. 3). However, the period between $600 \mathrm{BC}$ and AD 350 was relatively stable with a vegetation cover dominated by Corylus and Betula with 23-39\% and 12-23\% cover, respectively. Palynological richness varies between 22 and 27 dur- ing this period, and REVEALS-based evenness shows values between 0.71 and 0.78.

Between AD 350 and 750 changes in vegetation cover indicates land-use expansion followed by regression. We divided this interval into three parts, one expansion period and two regression phases (Fig. 5), based on changes in cover of open land taxa such as Poaceae, Cerealia type, early successional taxa such as Betula and late successional taxa such as Carpinus, Quercus, Tilia and Ulmus. We also took into account "other herbs", which include Calluna vulgaris, 

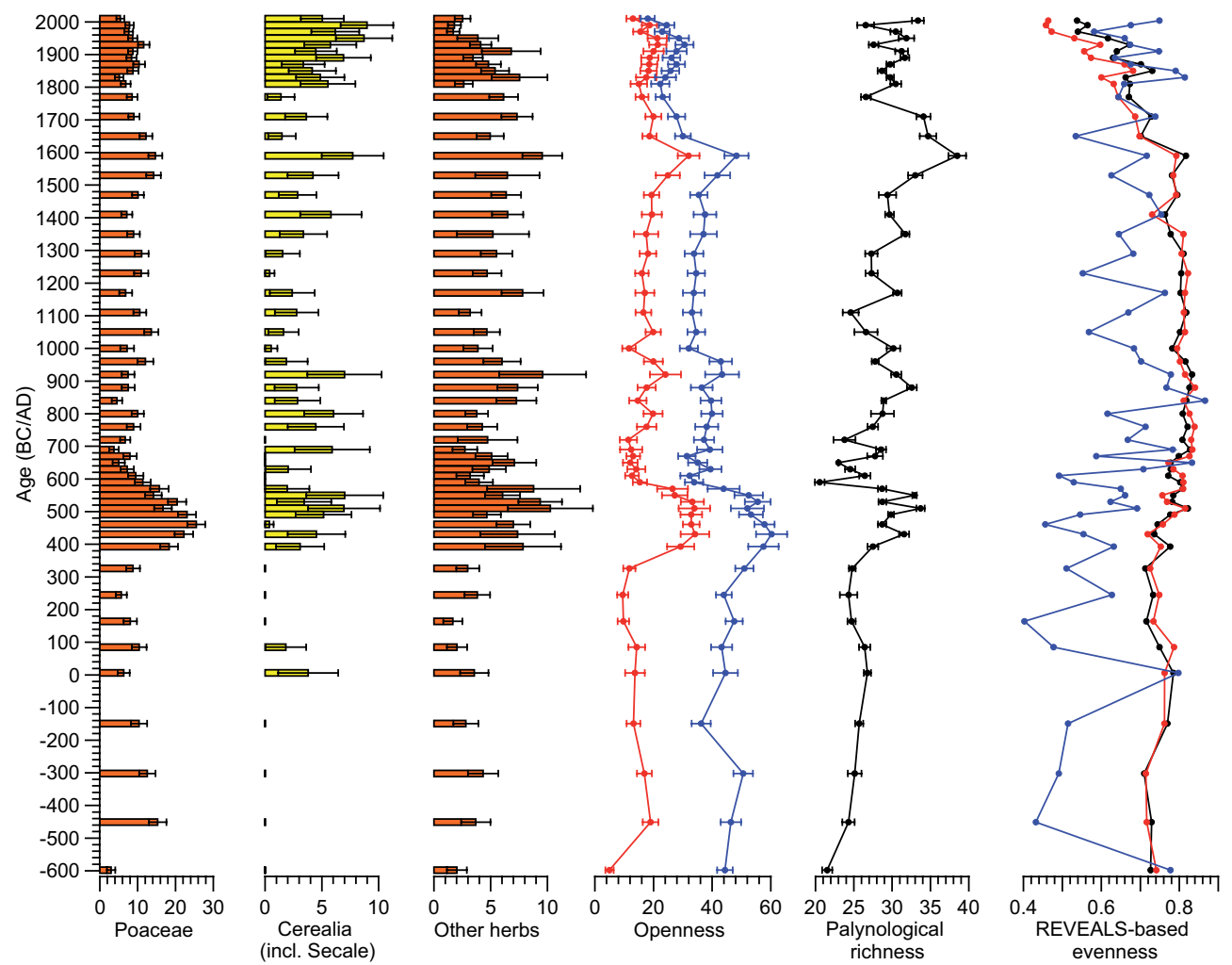

Fig. 4. Regional vegetation cover for selected taxa/taxa groups, openness, palynological richness and REVEALS-based evenness between $600 \mathrm{BC}$ to AD 2008. Openness was estimated both including and excluding shrubs (Juniperus and Corylus) shown by blue and red lines, respectively. REVEALS-based evenness was calculated for all 26 reconstructed taxa (black line), but also for trees (red line) and herbs (blue line) separately.

Compositae SF. Cichorioideae, Cyperaceae, Plantago lanceolata, Ranunculus acris type, Rubiaceae and Rumex acetosa type.

At the beginning of the expansion period AD 350 the cover of Cerealia type, Poaceae and other herbs increased significantly from 0 to $3 \%, 9$ to $18 \%$ and 3 to $8 \%$, respectively, which suggests a regional agricultural land-use expansion (Fig. 5). Simultaneously, Corylus decreased significantly in cover from 39 to $28 \%$. Poaceae shows maximum abundance at $\mathrm{AD} 450$ with $26 \%$ cover and decreased thereafter, whereas Cerealia type in general remained at higher values at least until AD 550. Both palynological richness and REVEALSbased evenness increased AD 350 to 550 and varied between 27 and 34 and between 0.74 and 0.82 , respectively. Also evenness for trees and herbs generally increased during this period.

At AD 550 we can observe an opposite pattern. The cover of Poaceae significantly decreased from 20 to $14 \%$, Cerealia type was only recorded in some samples and other herbs decreased in most samples, indicating an agricultural land-use regression (Fig. 5). At the same time Betula increased significantly in cover from 13 to $18 \%$. Between AD 650 and 750 the late-successional trees Carpinus, Quercus, Tilia and $U l$ $m u s$ increased significantly in cover from 16 to $22 \%$ and $B e$ - tula decreased. Between AD 550 and 750, REVEALS-based evenness remained at higher values between 0.77 and 0.83 , whereas palynological richness decreased to generally lower values between 21 and 29. Evenness for herbs and trees also remained at generally higher values.

At AD 750 late successional trees such as Carpinus, Quercus, Tilia and Ulmus decreased in cover from 20 to $16 \%$ (Figs. 3 and 5). Between AD 750 and 1000 Alnus shows a decreasing trend, whereas Betula increased. During the last 1000 yr Betula, Quercus, Tilia and Ulmus show decreasing trends, while Picea increased in cover from 6 to $61 \%$. Also Fagus increased gradually in cover starting at AD 1000 from 3 to $10 \%$, but decreased rapidly at ca. AD 1900 from 8 to $2 \%$ cover. Alnus had less cover between AD 1000 and 2008 compared to earlier periods. Corylus decreased during the last ca. $500 \mathrm{yr}$ and Juniperus was highest during the last $500 \mathrm{yr}$ but variable. Calluna vulgaris and Rumex acetosa type decreased in cover during the last ca. $150 \mathrm{yr}$ from 3 to $1 \%$ and from 1 to $0.5 \%$, respectively. REVEALS-based evenness decreased gradually from AD 1600 until today from 0.82 to 0.54 . Evenness for trees followed the same pattern as total evenness, but evenness for herbs remained at a higher level. 


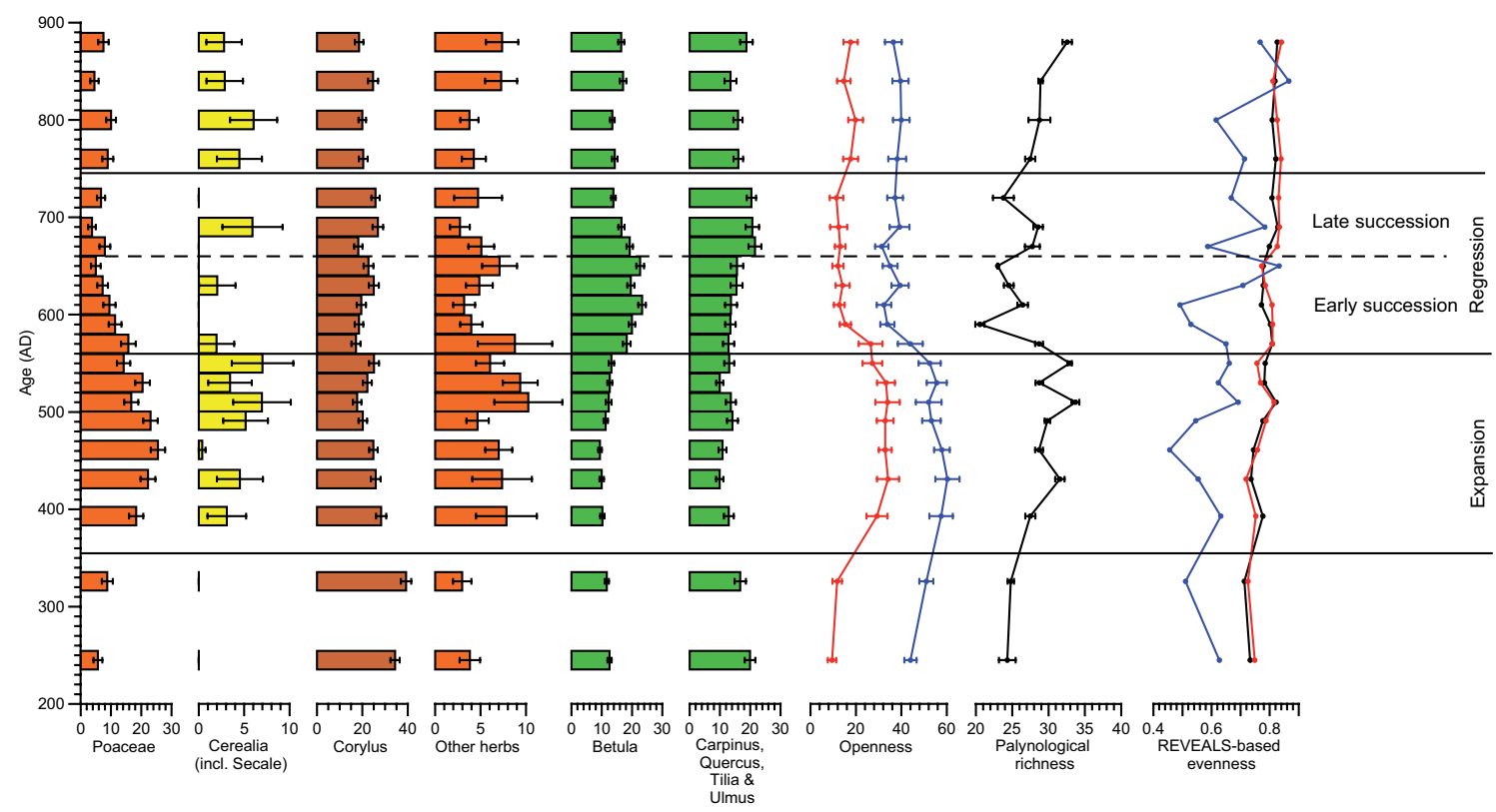

Fig. 5. Regional vegetation cover for selected taxa/taxa groups, openness, palynological richness and REVEALS-based evenness at the transition from expansion to regression AD 350 to 750. Openness was estimated both including and excluding shrubs (Juniperus and Corylus) shown by blue and red lines, respectively. REVEALS-based evenness was calculated for all 26 reconstructed taxa (black line), but also for trees (red line) and herbs (blue line) separately. The transition was divided into one expansion and two regression phases.

\section{Discussion}

We applied the study design suggested by Fredh et al. (2012), which includes high-resolution pollen analysis, quantitative vegetation reconstruction and estimates of both floristic richness and evenness. The quantified cover of taxa related to human impact allows us to estimate the extent of agricultural land use at different times and its relation to floristic diversity. However, it should be kept in mind that establishing a chronology for the Lake Fiolen sediment sequence was not straightforward despite our rather ambitious dating program involving a range of methods. The age-depth relationship in the interval between 160 and $40 \mathrm{~cm}$ is almost linear and in general parallel to the slope of the bulk dates. However, the interval between 40 and $20 \mathrm{~cm}$ reflects a more variable and generally lower sedimentation rate compared to the sections above and below. Possibly, there are other options to construct an age-depth model. However, given the available data, we consider our age-depth model the most probable one.

Between $600 \mathrm{BC}$ and AD 350 human impact was relatively low, but pollen grains of Cerealia and herbs related to human agriculture show that some anthropogenic land use occurred. The relatively large portion of Corylus, which requires some degree of openness, was possibly caused by widespread grazing (Berglund et al., 2002; Fyfe et al., 2008).

In general, Cerealia and most herbs had a higher cover during the last ca. $1650 \mathrm{yr}$, which suggests an increased agricultural land use and/or more focus on crop cultivation during this period. Palynological richness is generally higher during the same time, which suggests that traditional agriculture favoured floristic diversity. REVEALS-based evenness was highest between AD 500 and 1600, indicating more equal cover among taxa during this time. An increase in palynological richness is usually recorded at AD 1100 to 1200 in the uplands of southern Sweden as a consequence of increased land use (Lindbladh and Bradshaw, 1995; Sköld et al., 2010), although maximum palynological richness has been recorded at earlier times, between $500 \mathrm{BC}-\mathrm{AD} 1000$, in other areas in southern Sweden (Berglund et al., 2008).

Maximum openness (26-34\%), based on herb taxa cover dominated by Poaceae, was recorded at AD 350 to 550. This, together with increased Cerealia cover, suggests a maximum extent of agricultural land use at this time and could reflect an increased establishment of farms and permanent fields. It is also possible that grazing became more widespread during this period, which resulted in higher openness. In either way, the increase in open-land taxa at AD 350 is interpreted as a regional land-use expansion, which correlates with high values of both palynological richness and increase in evenness for both herbs and trees. This suggests that more species were present in the area and that they were represented by more equal cover, favoured by this land-use expansion. However, it should be noted that certain kinds of woodland management may also change tree pollen values, particularly for species that are coppiced or pollarded (e.g. Corylus), which could affect our openness estimations (Waller et al., 2012). Land-use expansions and regressions, similar to the one at $\mathrm{AD} 350$, have been observed throughout the last $6000 \mathrm{yr}$ in 
several pollen diagrams and may be related to periods of human population expansion and decline (Berglund, 1969; Lagerås, 2007).

This expansion was followed by a $200 \mathrm{yr}$ long interval of regression, which was recorded by decreased herb cover and increased tree cover (Fig. 4). The increased tree cover was recorded in two steps, first by early successional tree taxa such as Betula followed by late successional tree taxa such as Carpinus, Quercus, Tilia and Ulmus. This succession indicates that some areas were abandoned after AD 550, which allowed trees to expand on areas previously used for agricultural land use. During this land-use regression palynological richness decreased as several herb taxa disappeared from the record, which indicates this transition was unfavourable for some herbs. However, evenness for both trees and herbs remained at a higher level, and increased somewhat in the later part of the period, which reflect that the cover of the 26 taxa included in the REVEALS reconstruction was still rather equal. This regression period may be correlated to the Migration period AD 400-600, which was a period of societal change in Europe (Frenzel et al., 1994). Several pollen records from the uplands of southern Sweden indicate land abandonment during this period (Lagerås, 1996; Björkman, 1996).

Connell (1978) suggested the "intermediate disturbance hypothesis", which states that the highest biodiversity is created and maintained where disturbance is intermediate in frequency and intensity. Similarly, Emanuelsson (2005) suggested that land abandonment, like that observed at AD 550 in this study, is essential for biodiversity by allowing species groups favoured by traditional management, succession and old growth forest to coexist. However, in our study palynological richness declined simultaneously with land use, which suggests that species richness is not favoured during this type of succession, possibly due to rapid land abandonment. In contrast, Fredh et al. (2012) suggested that floristic diversity was favoured during the initial ca. $40 \mathrm{yr}$ of the transition from traditional to modern land-use management (ca. $100 \mathrm{yr}$ ago). However, during this type of transition the landscape was probably used to a similar extent as before, but changed from small-scale agriculture towards dominance of tree plantations and crop cultivation.

During the last ca. $100 \mathrm{yr}$ land use gradually changed from a small-scaled agriculture towards a modern land use based more on crop cultivation and forestry (Myrdal, 1997; Morell, 2001). This is supported in our record by decreased cover of most shrubs and herbs, such as Calluna vulgaris and Rumex acetosa type, and some trees, such as Fagus, Corylus and Betula, during the last ca. 100-150 yr, while Picea and Cerealia type increased. A decrease in palynological richness during the last ca. $100 \mathrm{yr}$ is sometimes observed in pollen records (Lindbladh and Bradshaw, 1995; Lindbladh, 1999; Sköld et al., 2010). In this study palynological richness decreased at $\mathrm{AD} 1700$, but remained within the range observed during the last 1650 yr. REVEALS-based evenness gradually decreased from AD 1600 until today, which suggests a decrease in habitats related the traditional agriculture. Evenness for herbs remained at a higher level probably due to the increase in Cerealia, which compensated for the decline of herb cover in general.

Previous pollen records, as well as archaeologi$\mathrm{cal} /$ historical records, from the region suggest maximum openness during the last ca. $1000 \mathrm{yr}$, often including a prominent expansion at ca. AD 900-1200 (Lindbladh and Bradshaw, 1995; Björkman, 1996; Lagerås, 1996; Lindbladh, 1999; Lindbladh et al., 2000; Andersson Palm, 2001; Berglund et al., 2002), which is not consistent with our record. However, some pollen diagrams do show equally high, and sometimes higher, openness between $\mathrm{AD} 0$ and 500 compared to the last $1000 \mathrm{yr}$ (Lagerås, 1996; Björkman, 1996). In the present study, Picea and Fagus increased gradually from $\mathrm{AD} 1000$, which is in agreement with estimates of the immigration of Picea to the region, whereas Fagus were present earlier but had a more patchy distribution (Lagerås, 1996; Bradshaw et al., 2000; Bradshaw and Lindbladh, 2005). Most previous pollen studies were based on small lakes and bogs, which partly reflect the local vegetation, since approximately 35 to $50 \%$ of the pollen assemblage originates from within few kilometers from small sites (1-100 ha) (Sugita, 1994). Therefore, it is not straightforward to compare these records with our pollen record reflecting regional vegetation. There are a few pollen-analytical studies based on medium sized lakes (approximately $75 \mathrm{ha}$ ) from the region, but the chronologies in these studies are based on bulk gyttja samples, which makes detailed dating of events difficult (Digerfeldt, 1972; Jacobson, unpublished data). Furthermore, Russian and Livingstone corers sometimes fail to recover the uppermost part of a sediment sequence, which may explain why a late 19th century maximum in land use is only recorded in a few pollen diagrams. Our study is also one of the first in the region using the Landscape Reconstruction Algorithm to correct for biases in pollen representation of vegetation.

Fredh et al. (2012) studied land-use and floristic diversity during the last $200 \mathrm{yr}$ in detail using the same sediment sequence but based on a different chronology. Although pollen percentages for some taxa do not differ so much between the chronologies covering the last $200 \mathrm{yr}$, the overall interpretation of the pollen record would be different using the chronology in this study. The main differences are in the interval AD 1800 to 1950 when Pinus, Betula, Corylus, have significantly larger cover, while Picea have significantly less cover in this study compared to Fredh et al. (2012). Fagus has significantly higher cover AD 1800 to 1880 and lower cover AD 1900 to 1940 in this study compared to Fredh et al. (2012). Palynological richness is similar between the two chronologies, but between AD 1800 and 1920 REVEALSbased evenness is higher with 0.75 to 0.83 compared to Fredh et al. (2012) with 0.63 to 0.73 . 
Fredh et al. (2012) interpreted the increase in Poaceae and many herbs at $\mathrm{AD} 1880$ as an increase in biomass rather than an increase in cover. This biomass increase was proposed to be connected to a reduction in grazing and mowing promoting flowering of grasses and herbs (i.e. a change to less intense agricultural land use). According to the chronology used in the present study the increase in Poaceae and many herbs occurred at AD 1500, which is a known period of expansion in the uplands of southern Sweden (Lagerås, 2007). Therefore, the change in cover of Poaceae and other herbs at this time could possibly be interpreted both as an expansion and a regression. Different interpretations are possible because Poaceae includes a large number of species which may react differently to land-use changes (Broström et al., 2008). During the last ca. $150 \mathrm{yr}$, grass cultivation increased, which may explain the relatively small change in Poaceae cover during this time, despite a decrease in extent of meadows and pastures.

We have been long aware that the traditional agricultural land use promotes floristic diversity (e.g. Emanuelsson, 2009), which is also supported in our study with higher estimates of floristic richness when crop cultivation and grazing becomes more widespread. However, this study is one of first that have used the REVEALS model to quantify the effect of modern land use on the landscape at a regional scale. REVEALS based evenness for the modern landscape is 0.54 compared to $0.70-0.83$ between $600 \mathrm{BC}$ and $\mathrm{AD} 1700$, i.e. strikingly low in a millennial perspective, which indicates that the present land-use management may not support a high floristic diversity in the long-term perspective. For the palynological richness the difference between the traditional agricultural landscape and modern land-use management is not as striking, however, lower today than between AD 1500 and 1700 . The landscape change during the last ca. $100 \mathrm{yr}$ is supported by historical data with increased Picea plantations and increased fragmentation, which may have implications, e.g. for seed dispersal (Antonsson and Jansson, 2011). Our results also provide response times of floristic diversity in a traditionally managed landscape during agricultural land-use expansion and regression, and during succession from open land to more tree covered vegetation. During the expansion of agricultural land-use AD 350 both palynological richness and REVEALS based evenness increased less than 20-50 yr after the first sign of expansion. A similar response time was recorded during the agricultural regression at AD 550 with a rapid decline (less than $20 \mathrm{yr}$ ) in palynological richness. These response times provide estimates of ecosystem resilience to agricultural land-use change. In the late succession of the regression there is a slight increase in palynological richness and REVEALS based evenness increased to the highest values (0.83) because of the increased cover of several of the broadleaved trees, which suggests that tree vegetation became more diverse.

Because the remaining areas with high biodiversity are few and fragmented, we need to optimise ecosystem man- agement to preserve species in the future. For this purpose, the regional landscape composition may be important e.g. for connectivity between the small fragments of traditional agricultural land use that remain. The adopted approach has the potential to be used also in other study areas with different vegetation and land-use history. However, to make knowledge about long-term processes more useful for ecosystem management it requires an active strategy to merge palaeoecology and modern records, as well as developing methods how to implement this kind of data in ecosystem management.

Acknowledgements. We thank Ian Snowball for help during fieldwork, Shinya Sugita for inputs on quantitative vegetation reconstruction and John Boyle for help with XRF measurements. We are also very thankful to all colleagues in the NordForsk LANDCLIM network (2009-2011) for useful discussions and comments on the study. This study was supported by grants from The Swedish Research Council Formas (Revealing the dynamics of discontinuous management and biodiversity at different spatial and temporal scales in the traditional cultural landscape), Helge Ax:son Johnson Foundation, Royal Physiographic Society in Lund, The Royal Swedish Academy of Sciences and The Swedish Foundation for International Cooperation in Research and Higher Education.

Edited by: P. Stoy

\section{References}

Aaby, B. and Digerfeldt G.: Sampling techniques for lakes and bogs, in: Handbook of Holocene Palaeoecology and Palaeohydrology, edited by: Berglund, B. E., John Wiley \& Sons, Chichester, 181-194, 1986.

Andersson Palm, L.: Folkmängden i Sveriges socknar och kommuner 1571-1997, Books-on-Demand, Göteborg, 2000.

Anton, C., Young, J., Harrison, P. A., Musche, M., Bela, G., Feld, C. K., Harrington, R., Haslett, J. R., Pataki, G., Rounsevell, M. D. A., Skourtos, M., Sousa, J. P., Sykes, M. T., Tinch, R., Vandewalle, M., Watt, A., and Settele, J.: Research needs for incorporating the ecosystem service approach into EU biodiversity conservation policy, Biodivers. Conserv., 19, 2979-2994, 2010.

Antonsson, H. and Jansson, U.: Agriculture and forestry in Sweden since 1900. The Royal Swedish Academy of Agriculture and Forestry, Stockholm, 2011.

Appleby, P. G.: Chronostratigraphic techniques in recent sediments, in: Tracking environmental change using lake sediments, edited by: Last, W. M. and Smol, J. P., Springer, Dordrecht, 171-203, 2001.

Autio, J. and Hicks, S.: Annual variations in pollen deposition and meteorological conditions on the fell Aakenustunturi in northern Finland: Potential for using fossil pollen as climate proxy, Grana, 43, 31-47, 2004.

Barnosky, A. D., Matzke, N., Tomiya, S., Wogan, G. O. U., Swartz, B., Quental, T. B., Marshall, C., McGuire, J. L., Lindsey, E. L., Maguire, K. C., Mersey, B., and Ferrer, E. A.: Has the Earth's sixth mass extinction already arrived?, Nature, 471, 51-57, 2011. 
Berglund, B. E.: Vegetation and human influence in South Scandinavia during Prehistoric time, Olikos Suppl, 12, 9-28, 1969.

Berglund, B. E. and Ralska-Jasiewiczowa, M.: Pollen analysis and pollen diagrams, in: Handbook of Holocene Palaeoecology and palaeohydrology, edited by: Berglund, B. E., John Willey \& Sons, Chichester, 455-484, 1986.

Berglund, B. E., Lagerås, P., and Regnell, J.: Odlingslandskapets historia i Sydsverige - en pollenanalytisk syntes, in: Markens minnen, edited by: Berglund, B. E. and Börjesson, K., Swedish National Heritage Board, Stockholm, 150-169, 2002.

Berglund, B. E., Persson, T., and Björkman, L.: Late Quaternary landscape and vegetation diversity in a north European perspective, Quatern. Int., 184, 187-194, 2008.

Beug, H.-J.: Leitfaden der Pollenbestimmung, Lieferung 1, Fischer, Stuttgart, 1961.

Beug, H.-J.: Leitfaden der Pollenbestimmung für Mitteleuropa und angrenzende Gebiete, Pfeil, München, 2004.

Birks, H. J. B. and Line, J. M.: The use of rarefaction analysis for estimating palynological richness from Quaternary pollenanalytical data, Holocene, 2, 1-10, 1992.

Björkman, L.: The Late Holocene history of beech Fagus sylvatica and Norway spruce Picea abies at stand-scale in southern Sweden, Ph.D. thesis, Lund University, 1996.

Boyle, J.: Rapid elemental analysis of sediment samples by isotope source XRF, J. Paleolimnol., 23, 213-221, 2000.

Bradshaw, R. H. W. and Lindbladh, M.: Regional spread and standscale establishment of Fagus sylvatica and Picea abies in Scandinavia, Ecology, 86, 1679-1686, 2005.

Bradshaw, R. H. W. and Webb, T.: Relationships between contemporary pollen and vegetation data from Wisconsin and Michigan, USA, Ecology, 66, 721-737, 1985.

Bradshaw, R. H. W., Holmqvist, B. H., Cowling, S. A., and Sykes, M. T.: The effect of climate change on the distribution and management of Picea abies in southern Scandinavia, Can. J. Forest Res., 30, 1992-1998, 2000.

Bronk Ramsey, C.: Deposition models for chronological records, Quaternary Sci. Rev., 27, 42-60, 2008.

Bronk Ramsey, C.: Bayesian analysis of radiocarbon dates, Radiocarbon, 51, 337-360, 2009.

Broström, A., Gaillard, M.-J., Ihse, M., and Odgaard, B.: Pollenlandscape relationship in modern analogues of ancient cultural landscapes in southern Sweden - a first step towards quantification of vegetation openness in the past, Veg. Hist. Archaeobot., 7, 189-201, 1998.

Broström, A., Sugita, S., and Gaillard, M.-J.: Pollen productivity estimates for the reconstruction of past vegetation cover in the cultural landscape of southern Sweden, Holocene, 14, 368-381, 2004.

Broström, A., Nielsen, A. B., Gaillard, M.-J., Hjelle, K., Mazier, F., Binney, H., Bunting, J., Fyfe, R., Meltsov, V., Poska, A., Räsänen, S., Soepboer, W., Von Stedingk, H., Suutari, H., and Sugita, S.: Pollen productivity estimates of key European plant taxa for quantitative reconstruction of past vegetation: a review, Veg. Hist. Archaeobot., 17, 461-478, 2008.

Brännvall, M.-L., Bindler, R., Emteryd, O., and Renberg, I.: Four thousand years of atmospheric lead pollution in northern Europe: A summary from Swedish lake sediments. J. Paleolimnol., 25, 421-435, 2001.
Connell, J. H.: Diversity in tropical rain forests and coral reefs, Science, 199, 1302-1310, 1978.

Davis, M. B.: Palynology after Y2K - understanding the source area of pollen in sediments, Annu. Rev. Earth. Pl. Sc., 28, 1-18, 2000.

Dawson, T. P., Jackson, S. T., House, J. I., Prentice, I. C., and Mace, G. M.: Beyond predictions: biodiversity conservation in a changing climate, Science, 332, 53-58, 2011.

Digerfeldt, G.: The post-glacial development of Lake Trummen. Regional vegetation history, water level changes and palaeolimnology, Folia limnologica scandinavica, 16, p. 104, 1972.

Eisenhut, G.: Untersuchungen über die Morphologie und Ökologie der Pollenkörner heimischer und fremdländischer Waldbäume, Parey, Hamburg, 1961.

Emanuelsson, U.: Ohävd - en nödvändig hävd, in: Arkeologi och naturvetenskap, edited by Bunte, C., Gyllenstiernska Krapperupstiftelsen, Nyhamnsläge, 111-128, 2005.

Emanuelsson, U.: The rural landscapes of Europe - How man has shaped European nature, FORMAS, Stockholm, 2009.

Fredén, C.: Geology. National atlas of Sweden, SNA, Stockholm, 1994.

Fredh, D., Broström, A., Zillén, L., Mazier, F., Rundgren, M., and Lagerås, P.: Floristic diversity in the transition from traditional to modern land-use in southern Sweden A.D. 1800-2008, Veg. Hist. Archaeobot., 21, 439-452, 2012.

Frenzel, M. E., Andersen, S. T., Berglund, B. E., and Gläser, B.: Evaluation of land surfaces cleared from forests in the Roman Iron Age and the time of migrating Germanic tribes based on reginal pollen diagrams, Fischer, Stuttgart,1994.

Froyd, C. A. and Willis, K. J.: Emerging issues in biodiversity \& conservation management: The need for a palaeoecological perspective, Quaternary Sci. Rev., 27, 1723-1732, 2008.

Fyfe, R. M., Brück, J., Johnston, R., Lewis, H., Roland, T. P., and Wickstead, H.: Historical context and chronology of Bronze Age land enclosure on Dartmoor, UK, J. Archaeol. Sci., 35, 22502261, 2008.

Gadd, C.-J.: Den agrara revolutionen 1700-1870, Natur och Kultur/LTs förlag, Stockholm, 2000.

Haslett, J. R., Berry, P. M., Bela, G., Jongman, R. H. G., Pataki, G., Samways, M. J., and Zobel, M.: Changing conservation strategies in Europe: A framework integrating ecosystem services and dynamics, Biodivers. Conserv., 19, 2963-2977, 2010.

Hellman, S., Gaillard, M.-J., Broström, A., and Sugita, S.: Effects of the sampling design and selection of parameter values on pollenbased quantitative reconstructions of regional vegetation: a case study in southern Sweden using the REVEALS model, Veg. Hist. Archaeobot., 17, 445-459, 2008a.

Hellman, S., Gaillard, M.-J., Broström, A., and Sugita, S.: The REVEALS model, a new tool to estimate past regional plant abundance from pollen data in large lakes: Validation in southern Sweden, J. Quatarnary. Sci., 23, 21-42, 2008b.

Hellman, S., Bunting, J., and Gaillard, M.-J.: Relevant source area of pollen in patchy cultural landscapes and signals of anthropogenic landscape disturbance in the pollen record: a simulation approach, Rev. Palaeobot. Palyno., 153, 245-258, 2009.

Hicks, S.: The relationship between climate and annual pollen deposition at northern tree-lines, Chemosphere, Global Change Sci., 1, 403-416, 1999.

Hyenstrand, Å.: Ancient monuments and prehistoric society, Swedish National Heritage Board, Stockholm, 1979. 
Jackson, S. T. and Hobbs, R. J.: Ecological restoration in the light of ecological history, Science, 325, 567-569, 2009.

Lagerås, P.: Vegetation and land-use in the Småland Uplands, southern Sweden, during the last 6000 years, Ph.D. thesis, Lund University, 1996.

Lagerås, P.: The ecology of expansion and abandonment. Medieval and Post-medieval land-use and settlement dynamics in a landscape perspective, Swedish National Heritage Board, Stockholm, 2007.

Larsson, L.-O.: Svedjebruket i Värend, in: Sydsmålänsk natur II, edited by: Mossberg, C., Kronobergs läns naturvetenskapliga förening, Växjö, 1974.

Levin, I. and Kromer, B.: The Tropospheric ${ }^{14} \mathrm{CO}_{2}$ Level in MidLatitudes of the Northern Hemisphere (1959-2003), Radiocarbon, 46, 1261-1272, 2004.

Levin, I., Hammer, S., Kromer, B., and Meinhardt, F.: Radiocarbon observations in atmospheric $\mathrm{CO}_{2}$ : Determining fossil fuel $\mathrm{CO}_{2}$ over Europe using Jungfraujoch observations as background, Sci. Total. Environ., 391, 211-216, 2008.

Lindbladh, M.: The influence of former land-use on vegetation and biodiversity in the boreo-nemoral zone of Sweden, Ecography, 22, 485-498, 1999.

Lindbladh, M. and Bradshaw, R. H. W.: The development and demise of a Medieval forest-meadow system at Linnaeus ' birthplace in southern Sweden: implications for conservation and forest history, Veg. Hist. Archaeobot., 4, 153-160, 1995.

Lindbladh, M., Bradshaw, R. H. W., and Holmqvist, B. H.: Pattern and processes in South Swedish forests during the last 3000 years, sensed at stand and reginal scales, J. Ecol., 88, 113-128, 2000.

MacDonald, G. M., Bennett, K. D., Jackson, S. T., Paducci, L., Smith, F. A., Smol, J. P., and Willis, K. J.: Impacts of climate change on species, populations and communities: palaeobiogeographical insights and frontiers, Prog. Phys. Geog., 32, 139-172, 2008.

Magurran, A. E.: Measuring biological diversity, Blackwell, Oxford, 2004.

Mazier, F., Gaillard, M.-J., Kuneš, P., Sugita, S., Trondman, A.K., and Broström, A.: Testing the effect of site selection and parameter setting on REVEALS-model estimates of plant abundance using the Czech Quaternary Palynological Database, Rev. Palaeobot. Palyno., 187, 38-49, 2012.

Meltsov, V., Poska, A., Odgaard, B. V., Sammul, M., and Kull, T.: Palynological richness and pollen sample evenness in relation to floristic diversity in southen Estonia, Rev. Palaeobot. Palyno., 166, 344-351, 2011.

Meltsov, V., Poska, A., Reitalu, T., Sammul, M., and Kull, T.: The role of landscape structure in determining palynological and floristic richness, Veg. Hist. Archaeobot., 22, 39-49, 2013.

Moberg, A., Sonechkin, D. M., Holmgren, K., Datsenko, N. M., and Karlén, W.: Highly variable Northern Hemisphere temperatures reconstructed from low- and high-resolution proxy data, Nature, 433, 613-617, 2005.

Moore, P. D., Webb, J. A., and Collinson, M. E.: Pollen analysis, 2nd Edn, Blackwell, Oxford, 1991.

Morell, M.: Jordbruket i industrisamhället 1870-1945, Natur och Kultur/LTs förlag, Stockholm, 2001.

Myrdal, J.: En agrarhistorisk syntes, in: Agrarhistoria, edited by: Larsson, B. M. P., Morell, M., and Myrdal, J., LTs Förlag, Stock- holm, 1997.

Myrdal, J.: Digerdöden, pestvågor och ödeläggelse. Ett perspektiv på senmedeltidens Sverige, Sällskapet Runica et Mediævalia, Stockholm, 2003.

Nielsen, A. B.: Modelling pollen sedimentation in Danish lakes at c. A.D. 1800: An attempt to validate the Pollscape model, J. Biogeogr., 31, 1693-1709, 2004.

Odgaard, B. V.: The Holocene vegetation history of northern west Jutland, Denmark. Council for Nordic Publications in Botany, Copenhagen, 1994.

Odgaard, B. V.: Fossil pollen as a record of past biodiversity, J Biogeogr, 26, 7-17, 1999.

Odgaard, B. V.: Reconstructing past biodiversity development, in: Encyclopedia of Quaternary science, edited by: Elias, S. A., Elsevier, Amsterdam, 2508-2514, 2007.

Peros, M. C. and Gajewski, K.: Testing the reliability of pollenbased diversity estimates, J. Paleolimnol., 40, 357-368, 2008.

Pielou, E. C.: The measurement of diversity in different types of biological collections, J. Theor. Biol., 13, 131-144, 1966.

Poschlod, P., Bakker, J. P., and Kahmen, S.: Changing land use and its impact on biodiversity, Basic Appl. Ecol., 6, 93-98, 2005.

Prentice, I. C.: Pollen representation, source area, and basin size: Toward a unified theory of pollen analysis, Quaternary. Res., 23, 76-86, 1985.

Punt, W.: The northwest European pollen flora I-VIII, Elsevier, Amsterdam, 1976-2003.

Raab, B. and Vedin, H.: Climate, lakes and rivers, National atlas of Sweden, SNA, Stockholm, 1995.

Reimer, P. J., Baillie, M. G. L., Bard, E., Bayliss, A., Beck, J. W., Blackwell, P. G., Bronk Ramsey, C., Buck, C. E., Burr, G. S., Edwards, R. L., Friedrich, M., Grootes, P. M., Guilderson, T. P., Hajdas, I., Heaton, T. J., Hogg, A. G., Hughen, K. A., Kaiser, K. F., Kromer, B., McCormac, F. G., Manning, S. W., Reimer, R. W., Richards, D. A., Southon, J. R., Talamo, S., Turney, C. S. M., van der Plicht, J., and Weyhenmeyer, C. E.: IntCal09 and Marine09 radiocarbon age calibration curves, $0-50,000$ years cal BP, Radiocarbon, 51, 1111-1150, 2009.

Renberg, I. and Hansson, H.: The HTH sediment corer, J. Paleolimnol., 40, 655-659, 2008.

Renberg, I., Bindler, R., and Brännvall, M-L.: Using the historical atmospheric lead-deposition record as a chronological marker in sediment deposits in Europe, Holocene, 11, 511-516, 2001.

Sjörs, H.: Amphi-atlantic zonation, nemoral to arctic, in: North Atlantic biota and their history, edited by: Löve, A. and Löve, D., Pergamon, Oxford, 109-125, 1963.

Sköld, E., Lagerås, P., and Berglund, B. E.: Temporal cultural landscape dynamics in a marginal upland area: Agricultural expansions and contractions inferred from palynological evidence at Yttra berg, southern Sweden, Veg. Hist. Archaeobot., 19, 121136, 2010.

Stuart, A. and Ord, J. K.: Kendall's advanced theory of statistics, vol 1. Distribution theory, Arnold, London, 1994.

Sugita, S.: A model of pollen source area for an entire lake surface, Quaternary Res., 39, 239-244, 1993.

Sugita, S.: Pollen representation of vegetation in Quaternary sediments: Theory and method in patchy vegetation, J. Ecol., 82, 881-897, 1994.

Sugita, S.: Theory of quantitative reconstruction of vegetation I: Pollen from large sites REVEALS regional vegetation compo- 
sition, Holocene, 17, 229-241, 2007a.

Sugita, S.: Theory of quantitative reconstruction of vegetation II: All you need is LOVE, Holocene, 17, 243-257, $2007 \mathrm{~b}$.

Sugita, S., Gaillard, M.-J., and Broström, A.: Landscape openness and pollen records: A simulation approach, Holocene, 9, 409421, 1999.

Thompson, R., Bloemendal, J., Dearing, J. A., Oldfield, F., Rummery, T. A., Stober, J. C., and Turner, G. M.: Environmental applications of magnetic measurements, Science, 207, 481-486, 1980.

Van der Knaap, W. O.: Estimating pollen diversity from pollen accumulation rates: A method to assess taxonomic richness in the landscape, Holocene, 19, 159-163, 2009.

Van Dyke, F.: Conservation Biology: Foundations, Concepts, Applications, 2nd Edition, Springer, Dordrecht, 2008.
Waller, M., Grant, M. J. and Bunting, M. J.: Modern pollen studies from coppiced woodlands and their implications for the detection of woodland management in Holocene pollen records, Rev. Palaeobot. Payno., 187, 11-28, 2012.

Welinder, S., Pedersen, E. A., and Widgren, A.: Jordbrukets första femtusen år 4000 f. Kr. - 1000 e. Kr, Natur och Kultur/LTs förlag, Stockholm, 2004.

Willis, K. J. and Bhagwat, S. A.: Questions of importance to the conservation of biological diversity: answers from the past, Clim. Past, 6, 759-769, doi:10.5194/cp-6-759-2010, 2010.

Willis, K. J., Bailey, R. M., Bhagwat, S. A., and Birks, H. J. B.: Biodiversity baselines, thresholds and resilience: Testing predictions and assumptions using palaeoecological data, Trends. Ecol. Evol., 25, 583-591, 2010. 